\title{
Comparison Study: Cost of Electricity, Emission, and Renewable Fraction for Single Residential Load at Geelong, Victoria State- Australia using HOMER
}

\author{
Harish Kumar R. N., Member, IACSIT
}

\begin{abstract}
This paper presents a comparison of change in Cost of Electricity (COE) (\$), Emission (Kilogram/year-kg/yr), and Renewable Fraction (RF) for a single residential load at Geelong with five different methodologies. The National Renewable Energy Laboratory (NREL) optimization computer model for distributed power, "HOMER," is used to study the comparison. The first analysis with system 1 showed that, a 10.5 kilo-Watt (kW) Photovoltaic (PV) module (supporting 10.5 kW converter was opted, and 33 batteries $(4$ volts $(\mathrm{V}))$, Nominal capacity 1900 Amp-hour (Ah)) is must to supply electricity for a single residential load with available solar radiation exposure, and the obtained COE, Emission, and RF are \$0.35, zero, 1.00. The second analysis with system 2 showed that excess electricity generated can be sold to the grid, and the obtained COE- $\$ 0.30$, Emission- -2250 kg/yr carbon-dioxide $\left(\mathrm{CO}_{2}\right),-5.41 \mathrm{~kg} / \mathrm{yr}$ Nitrogen oxide $\left(\mathrm{N}_{2} \mathrm{O}\right),-11.1 \mathrm{~kg} / \mathrm{yr}$ sulphur dioxide $\left(\mathrm{SO}_{2}\right)$, and RF 0.85. The third analysis with system 3 showed that with an optimized number of batteries a higher RF and reduced COE can be achieved, and excess electricity produced can be sold to the grid; the obtained COE- \$ 0.14, Emission- -4,386 kg/yr $\mathrm{CO}_{2}$, $-19 \mathrm{~kg} / \mathrm{yr} \mathrm{SO} \mathrm{S}_{2},-9.1 \mathrm{~kg} / \mathrm{yr} \mathrm{N}_{2} \mathrm{O}$ and RF-0.80. The fourth analysis with system 4 showed that there is a reduction in the percentage of $\mathrm{RE}$ factor and escalating price of COE, obtained COE- \$0.18, Emission - $5055 \mathrm{~kg} / \mathrm{yr} \mathrm{CO},-10.7 \mathrm{~kg} / \mathrm{yr} \mathrm{N} \mathrm{N}_{2} \mathrm{O}, 21.9 \mathrm{~kg} / \mathrm{yr} \mathrm{SO} \mathrm{S}_{2}$, and RF- 0.80. The fifth analysis with system 5 showed that house load connected to only grid emits significant amount of Emission, the obtained COE, 0.26\$, Emission - $3691 \mathrm{~kg} / \mathrm{yr} \mathrm{CO}_{2}$, $16 \mathrm{~kg} / \mathrm{yr} \mathrm{SO}, 7.83 \mathrm{~kg} / \mathrm{yr} \mathrm{N} \mathrm{N}_{2} \mathrm{O}$ and RF- 0.80 .
\end{abstract}

Index Terms-Photovoltaic (PV) modules, primary house load, battery, grid, converter, renewable energy (RE).

\section{INTRODUCTION}

Australia is the seventeenth largest in using non-renewable energy resources and ranks eighteenth on per person basis around the world. The main Non-renewable energy primary resources used in Australia are coal, oil, gas, and related products, which represents 96 per cent of total energy consumption.

The remaining 4 percent is Renewable sources with majority of Bio-energy (wood and wood waste, biomass, and biogas). However, in the recent years, RE consumption is growing strongly [1].

The majority of powers supplied in houses by state or local power authority throughout Australia are 240-volt alternating current (AC). However, few house owners find the prices of the electricity connected through grid to the houses are

Manuscript received November 5, 2013; revised December 24, 2013.

Harish Kumar R N is with School of Engineering, Deakin University, 75 Pigdons Rd, Waurn Ponds, Geelong VIC 3216, Australia (e-mail: harish.nvhph@gmail.com). expensive [2]. Historically Australia had competitive and stable electricity prices, due to developed world standards in the recent years, the electricity price in the tariff has risen 70 percent nationally. This is because of the fact that the transmission and distribution lines which deliver electricity to houses are becoming older, and it's now time to replace with new ones, which over all requires a huge capital investment, and these investments are imposed on the electricity prices [3].

Australia has predicted 20 - 2020 i.e. 20 percent of RE usage by 2020 [4]. Within RE technology, by considering less moving parts, less area occupancy and easy installable devise for a typical house, PV modules are best suitable to supply electricity.

\section{BACKGROUND}

In Australia, average house hold electricity charges in the year 2012-13 are discussed below, and is also shown in Fig. 1

1) Network charge-These charges accounts 51 percent of the bill, which mainly includes cost of building, and for maintaining electricity networks such as electric poles and wires which deliver electricity to houses.

2) Whole sale cost-These charges accounts 20 percent of the electricity bill, which mainly includes cost associated with generated electricity and for trading in whole sale market.

3) Retail and energy scheme costs - It includes 20 percent of the bill for the 'shop front' i.e. for consumer's electricity supply and costs from schemes for energy efficiency and renewable.

4) Carbon price-Around 9 percent of the cost is added to the electricity bill for carbon emission by fuel generators [3].

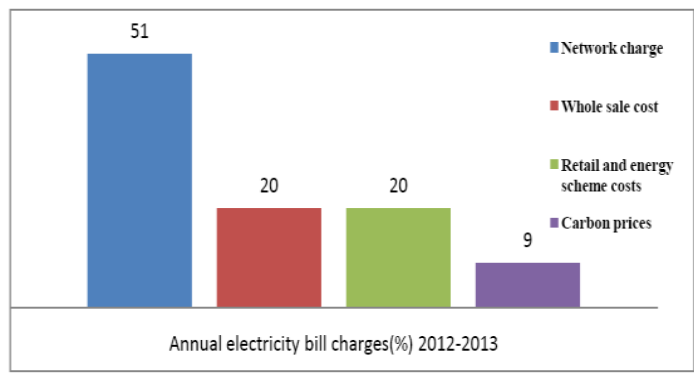

Fig. 1. Various cost factors involved in Electric bill

However an alternate solution i.e PV modules can be used to eliminate the charges imposed on electricity bills [3]. A PV module generates direct current (DC), which is directly proportional to the available global solar radiation [5]. Hence the DC output from PV module can be calculated using (1) 
[6], and its efficiency can be calculated using (2) [4].

$$
P_{P V}=f_{P V} \times Y_{P V}\left(\frac{I_{T}}{I_{s}}\right) 1
$$

where, $f_{P V}-\mathrm{PV}$ de-rating factor [percent \%].

$Y_{P V}$ - Rated capacity of the PV panel Kilowatt [kW],

$I_{T}$ - Global solar-radiation $\left[\mathrm{W} / \mathrm{m}^{2}\right]$, and

$I_{S}-1000 \mathrm{Watt}$ per square meter $\left[\mathrm{W} / \mathrm{m}^{2}\right]$, standard amount of radiation:

$$
\text { Solarefficiency }(\%)=\left(\frac{\text { Powerout }}{\text { Powerin }}\right) \text { ink } W \times 100
$$

The most important factor is identifying the value of a PV system, and is calculated using equation (3) [4].The simple payback time/year of PV module can be calculated using (4) [4].

$$
\begin{aligned}
\$ / \mathrm{W} & =\left(\begin{array}{l}
\frac{\text { Upfront cost of the PV system }(\$)}{2 \text { Rated Peak Power of the } P V} \\
\text { system avoided electricity purchase }
\end{array}\right) \\
\$ / \mathrm{W} & =\left(\frac{\text { Capital cost }(\$)}{\text { Savings from avoided electricity purchase }}\right)
\end{aligned}
$$

Before installing a PV module, PV sizing is must, as it allows identifying the required PV module wattage to supply electricity to the house load, and is calculated using (5) [4], [7] Watts-hour per day $=$ Solar Irradiance $\mathrm{kWh} / \mathrm{m}^{2} \times($ Panel
Wattage $\times$ de-rating factor $)$

Carbon-dioxide is a very important factor for energy intensity of an economy. Emission intensity is defined as the amount of green house gases emitted per unit of energy used. Per Capita is defined as the measure of the amount of energy used per unit of economic activity generated, and is calculated using (6) [8].

GDP per capita is gross domestic product divided by midyear population.

$$
\begin{aligned}
\text { Per capita }= & \text { GDP per capita } \times \text { Energy } / \text { GDP } \times \\
& \mathrm{CO}_{2} / \text { Energy }
\end{aligned}
$$

By considering above all factors finally COE plays a vital role, as people are concerned with the payments made for Electricity bills, and is calculated using (7) [9].

$$
\operatorname{COE}(\$)=\frac{C_{\text {ann.tot }}}{E_{I S}+E_{\text {grid }}}
$$

where, $C_{a n n, t o t}$ is the annual total cost, $(\$)$.

$E_{l s}$ - Electrical energy supplied by the grid system [kWh/yr] and $E_{\text {grid }}$-Amount of electricity sold to the grid $[\mathrm{kWh} / \mathrm{yr}]$, and the electricity sold to grid can be calculated using “(8)

$$
\text { Gridsales }(\$)=\text { Sell Back rate } \times \text { Gridsales }\left(\frac{k w h}{y r}\right)
$$

\section{APPROACH METHODOLOGY}

Various feasible approaches were looked upon to identify optimum COE, Emission, and RF, which are listed in Table I. In total, 5 systems were designed to understand and identity the optimum system model for Geelong location. System 1, 2, 3 , and 4 were designed to achieve majorly with PV RE source. System 2, 3, 4 and 5 were modeled with an assumption that a grid connection is available near the house location.

TABLE I: APPROACH METHODOLOGY

\begin{tabular}{lccc}
\hline \hline System & Grid & PV+ Converter & Battery \\
\hline 1 & & $\checkmark$ & $\checkmark$ \\
2 & $\checkmark$ & $\checkmark$ & $\checkmark$ \\
3 & $\checkmark$ & $\checkmark$ & $\checkmark$ \\
4 & $\checkmark$ & $\checkmark$ & \\
5 & $\checkmark$ & & \\
\hline \hline
\end{tabular}

\section{PRIMARY House LOAD}

The hourly, daily, monthly and annual load profile for a typical house is as shown in the Fig. 2. From Fig. 2. it can be noticed that the load varies at each different time in a day; the maximum demand occurs during the day time i.e. only between 7 am to $10 \mathrm{am}$, the reasons is all family members get ready to office and school, and return home after $5 \mathrm{pm}$, after which the peak demand starts and electricity load reduces eventually when the day gets over.

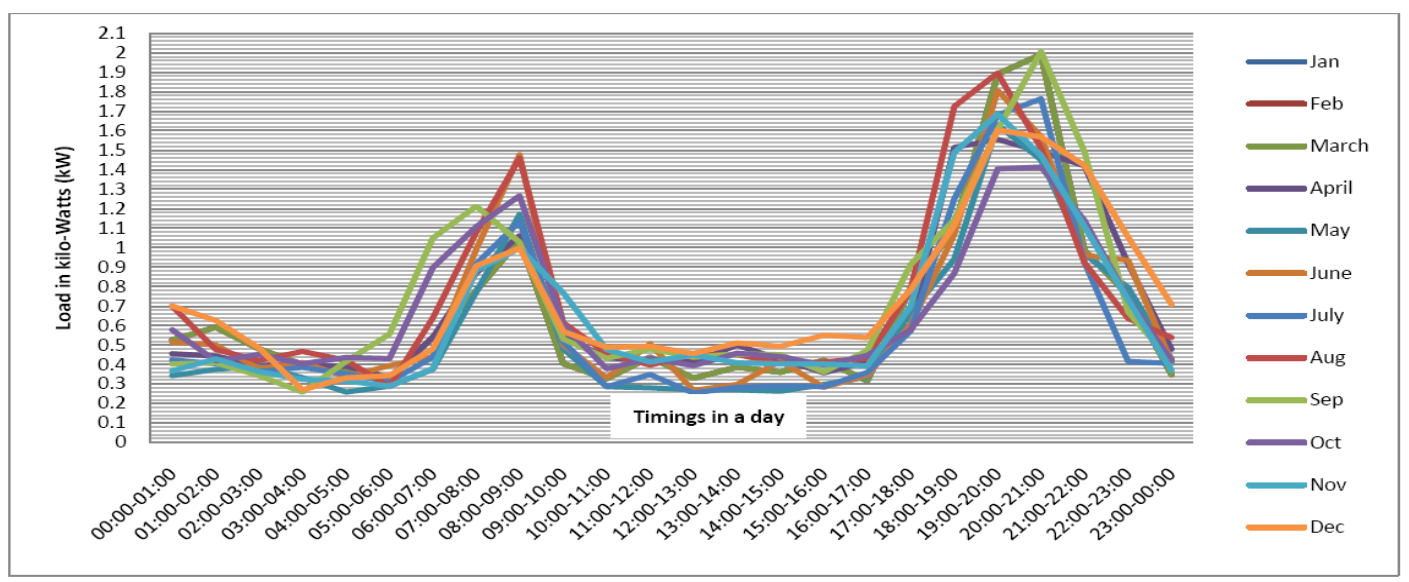

Fig. 2. Primary house load recorded at Geelong. 
The baseline anual average is 15.9 kilo-Watt hour/day $(\mathrm{kWh} / \mathrm{d})$ and HOMER scaled anual average is $16 \mathrm{kWh} / \mathrm{d}$. The average baseline load is 0.664 kilo-Watt $(\mathrm{kW})$, and HOMER average scaled load is $4.15 \mathrm{~kW}$, and both the baselins, scaled input HOMER load factor is 0.16 .

\section{COSTS AND INFORMATION}

The current prices of Grid connected COE (without any discounts) for peak ( $3 \mathrm{pm}-9 \mathrm{pm})$, shoulder (7 am-3 pm, 9 pm-10 pm), and off peak (10 pm-7 am) timings, and sell back rate are listed in the Table II. The input cost and information in HOMER for PV module, Converter, and Battery are listed in Table III, Table IV, and Table V.

TABLE II: GRID ELECTRICITY PRICES-VICTORIA STATE

\begin{tabular}{lllll}
\hline \hline Description & Timing & Days & $\ldots$ & $\begin{array}{l}\text { Cost inc } \\
\text { GST } \\
(\$ / \mathrm{kWh})\end{array}$ \\
\hline Peak & $\begin{array}{l}3 \mathrm{pm}-9 \mathrm{pm} \\
7 \mathrm{am}-3 \mathrm{pm}\end{array}$ & Mon-Fri & $\ldots$ & 0.3878 \\
Shoulder & $9 \mathrm{pm}-10 \mathrm{pm}$ & Mon-Fri & $\ldots$ & 0.2724 \\
Off peak & $10 \mathrm{pm}-7 \mathrm{am}$ & Mon-Sun & $\ldots$ & 0.1775 \\
Sellback rate & All time & All day & $\ldots$ & 0.08 \\
\hline \hline
\end{tabular}

TABLE III: PV MODULE COST AND INFORMATION

\begin{tabular}{ll}
\hline \hline Channels & Cost/Information \\
\hline Capital cost & $\$ 1000.00$ per KW \\
Replacement cost & $\$ 800.00$ per KW \\
Operation and Maintenance cost & $\$ 50.00$ per year \\
Life time & 25 years \\
PV tracking system & No tracking \\
De-rating factor & $85 \%$ \\
Slope & $38.2833^{\circ}$ \\
Azimuth & $180^{\circ}$ \\
Ground reflectance & $20 \%$ \\
\hline \hline
\end{tabular}

TABLE IV: CONVERTER COST AND INFORMATION

\begin{tabular}{ll}
\hline \hline Description & Cost/information \\
\hline Capital cost & $\$ 200.00$ \\
Replacement cost & $\$ 170.00$ \\
Efficiency & $90 \%$ \\
Life time & 15 \\
\hline \hline
\end{tabular}

TABLE V: BATTERY COST AND INFORMATION

\begin{tabular}{ll}
\hline \hline Description & Cost/information \\
\hline Capital cost & $\$ 170.00 / 4 \mathrm{~V} \mathrm{1900 \textrm {AH }}$ \\
Replacement cost & $\$ 130.00 / 4 \mathrm{~V} \mathrm{1900 \textrm {AH }}$ \\
Batteries per string & 1 \\
Float life & 12 years \\
\hline \hline
\end{tabular}

\section{RESUlTS AND DISCUSSION}

\section{A. Solar Radiation and Clearness Index}

The solar radiation of each month for the year 2012 was collected from Bureau of Metrology (BOM) [10], and the data was imported in HOMER NREL tool. With the solar data, the regions Latitude and Longitude i.e. $38^{\circ} .17^{\prime}$ South, and $144.38^{\prime}$ East and the time zone as "GMT + 10:00 Melbourne, Sydney, Guam, Port Moresby" was selected. The HOMER tool automatically simulates clearness index as shown in the Fig. 3. An average of 4.378 kilo-Watt hour/square meter $\left(\mathrm{kWh} / \mathrm{m}^{2} / \mathrm{d}\right)$ horizontal solar radiation and a clearness index of 0.538 are available in the selected Geelong location. The clearness index can be calculated using (8) [11].

$$
\text { Clearnessindex }(k)=\frac{H_{g}}{H_{o}}
$$

where, $H_{g}$ Measured Solar Radiation

$H_{0}$ Extraterrestrial Solar Radiation, in eq. (9) [11].

$H_{0}=\frac{24}{\pi} \operatorname{Isc}\left(1+0.33 \frac{360}{365} n\right)\left(\omega \frac{\pi}{180} \sin \phi \sin \delta+\cos \phi \cos \delta \sin \omega(9)\right.$

where $\phi$ is the latitude (radiance),

$\delta$ - Solar declination angle (radiance), calculated using (10) [12]

$\omega$ - Sunset hour angle for typical day, and calculated using (11) [11]

$n$ - The day of the year. Example: for January first, $n=1$ i.e. number of days in a year ( 1 to 365 )

$$
\begin{gathered}
\delta=23.45+\sin \left[(284+n) \times \frac{360}{365}\right] \\
\omega=\cos ^{-1}[-\tan \phi \times \tan \delta]
\end{gathered}
$$

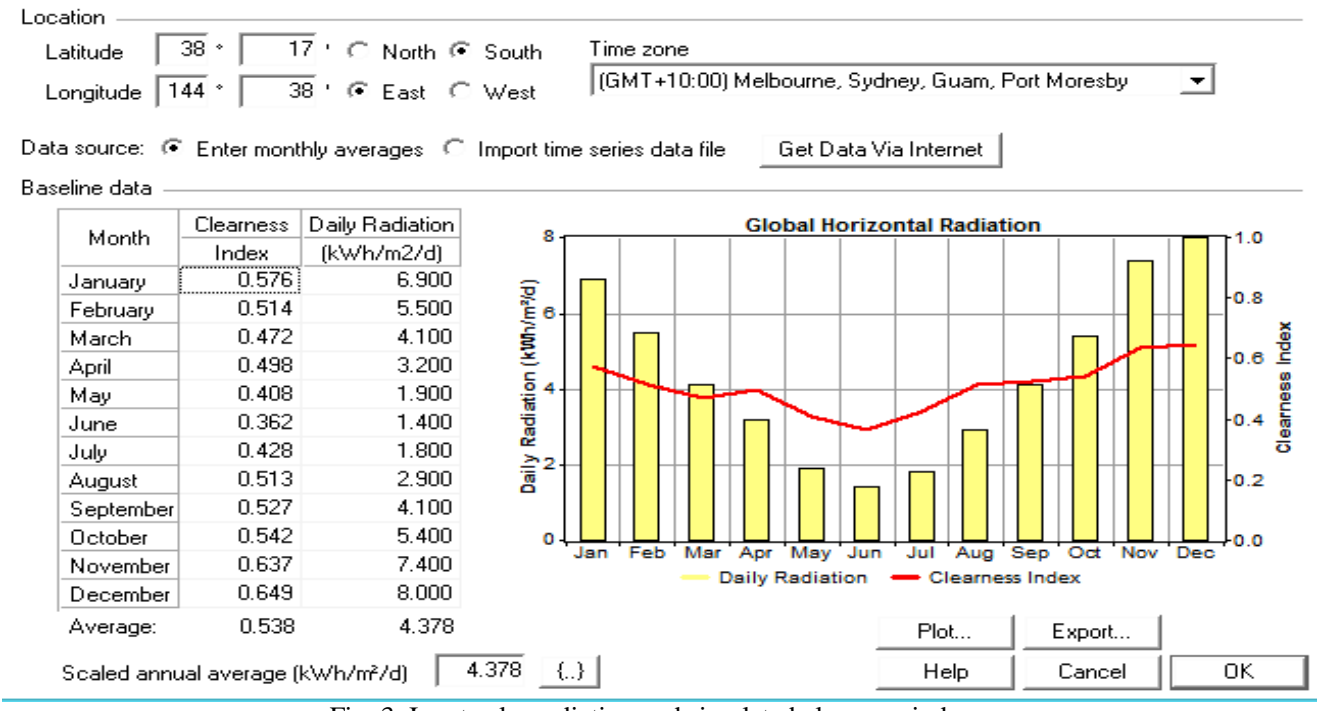

Fig. 3. Input solar radiation and simulated clearness index. 


\section{B. Electricity Price Distribution}

The current 2012-2013 electricity prices of Victoria State are equally distributed in HOMER i.e. peak, off peak, shoulder periods, sell back rate, and was enabled in the scheduled prices to the grid connected primary house load as shown in the Fig. 4.
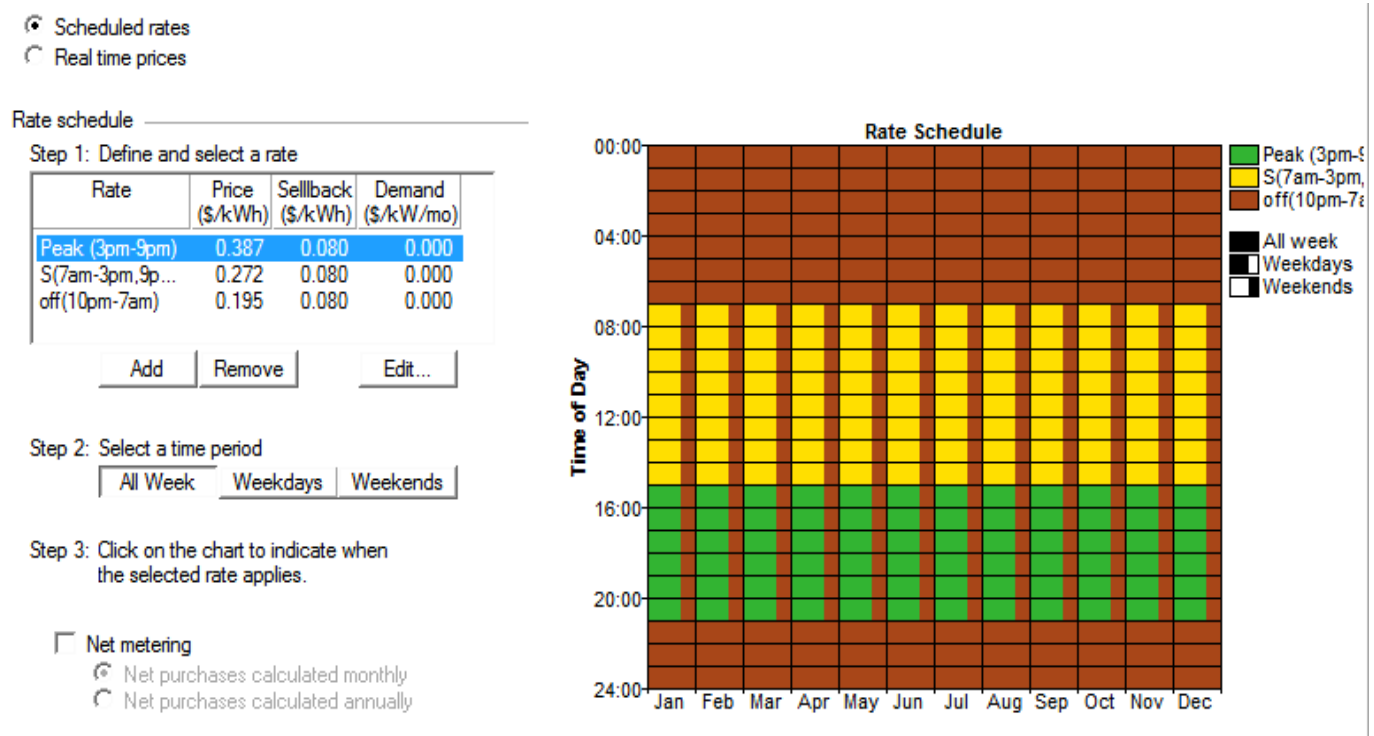

Fig. 4. Grid connected COE distribution for whole year, and timings.

\section{1ST Approach (PV-Converter-Battery)}

The design of system 1 is as shown in the Fig. 5. System 1 was modeled with an attempt to achieve $100 \%$ RE with PV modules, and was sized by considering various system losses and with the available solar radiation.

System 1 was designed in HOMER tool for recorded primary house load. The output from PV is not always same at each time, day and month as it majorly depends on the solar radiation. Hence, with these reasons an extra watts PV was designed by conducting multiple iterations in HOMER in order to meet the required load all the time i.e. a $10.5 \mathrm{~kW}$ PV module, $10.5 \mathrm{~kW}$ converter, and 33 batteries was sized instead of the actual house load $16 \mathrm{kWh} / \mathrm{d}(4.2 \mathrm{~kW})$ peak as shown in the Fig. 6. The $10.5 \mathrm{~kW}$ annually generates 15,337 $\mathrm{kWh} / \mathrm{yr}$ direct current (DC), however the primary alternative current (AC) house load is only $5837 \mathrm{~kW}$, i.e. an excess electricity after converter losses of $7860 \mathrm{kWh} / \mathrm{yr} \mathrm{AC}$ is unused and increasing the levelized COE. With the designed system an Initial capital cost of $\$ 18,210$, operating cost of \$225, \$ 21,091 Net Present Cost (NPC), levelized COE $\$ 0.283 / \mathrm{kWh}$ and RF 1 was obtained as shown in the Fig. 7.

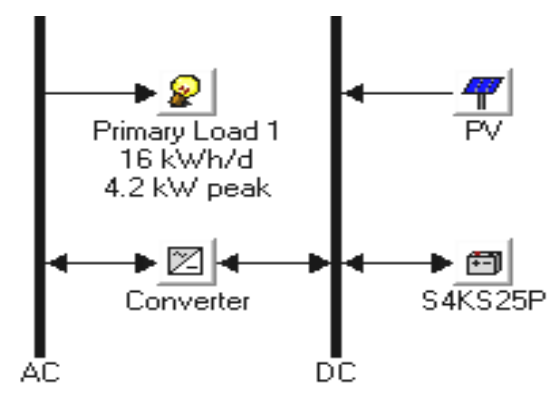

Fig. 5. System 1: PV stand alone system.

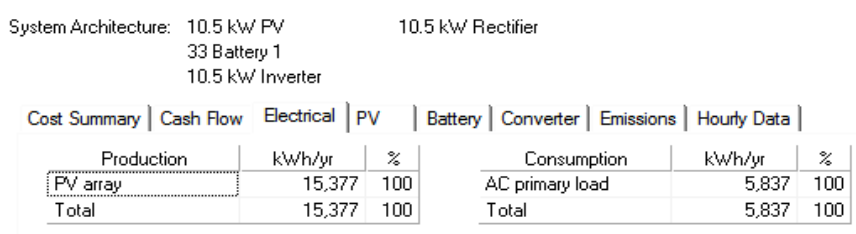

Total NPC: $\$ 21,091$

Levelized COE: $\$ 0.283 / \mathrm{kWh}$ Operating Cost: $\$ 225 / y r$

\begin{tabular}{l|r|r|}
\multicolumn{1}{c|}{ Quantity } & \multicolumn{1}{c|}{ kWh/yr } & \multicolumn{1}{c|}{$\%$} \\
\hline Excess electricity & 7.860 & 51.1 \\
Unmet electric load & 2.95 & 0.1 \\
Capacity shortage & 3.45 & 0.1 \\
\hline \multicolumn{1}{|c|}{ Quantity } & \multicolumn{2}{|c|}{ Value } \\
\hline Renewable fraction & \multicolumn{2}{|c|}{1.00} \\
\hline
\end{tabular}

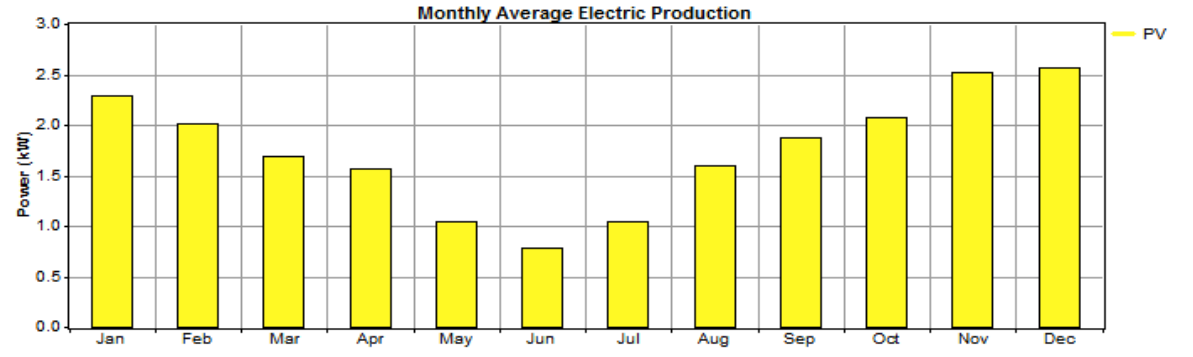

Fig. 6. Monthly average electricity production. 


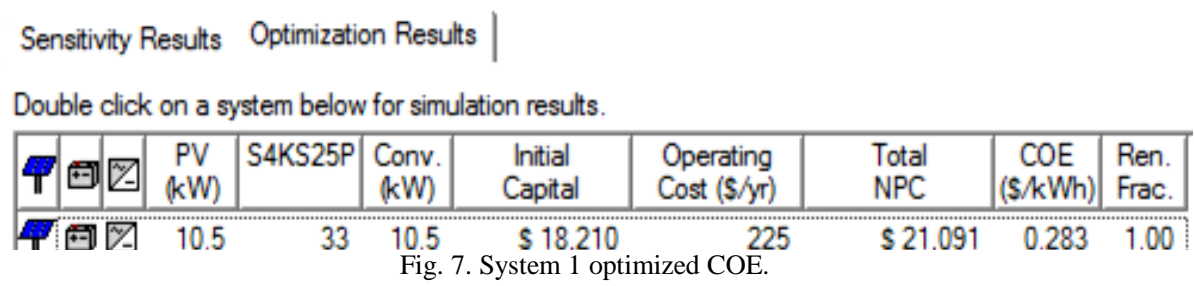

\section{D. $2^{\text {nd }}$ Approach (PV-Converter-Battery-Grid)}

By considering the unused electricity and escalating levelized COE, a second approach was designed as show in the Fig. 8. The modeled System 2 is similar as system 1, but the system is connected to grid. The system connected to the grid has an advantage of using the grid connected electricity whenever the electricity is un-met to the house load from PV, and the unused electricity can be sold to the grid.

86 percent of the PV output is used to supply house load, where as the remaining i.e. AC $6,523 \mathrm{kWh} / \mathrm{yr}$ electricity is sold to the grid, and the unmet electricity during the demand hours is purchased from the Grid. Still an excess electricity of AC 1,661 kWh/yr is stored in the battery as shown in Fig. 9. With the designed system an Initial capital cost of $\$ 18,210$, operating cost of $\$ 332, \$ 22,450$ NPC, levelized COE $\$ 0.30 / \mathrm{kWh} 1$ and RF 0.86 was obtained as shown in the Fig. 10 .

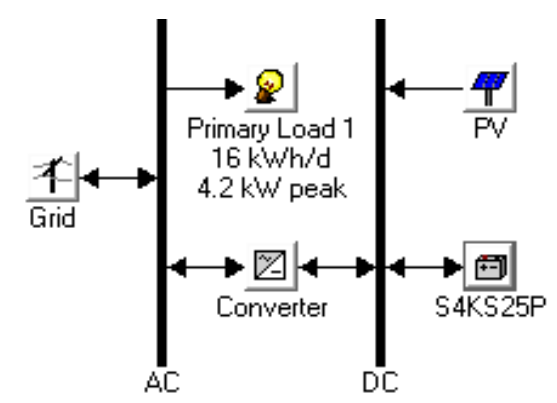

Fig. 8. System 2: Grid connected PV-converter- battery.
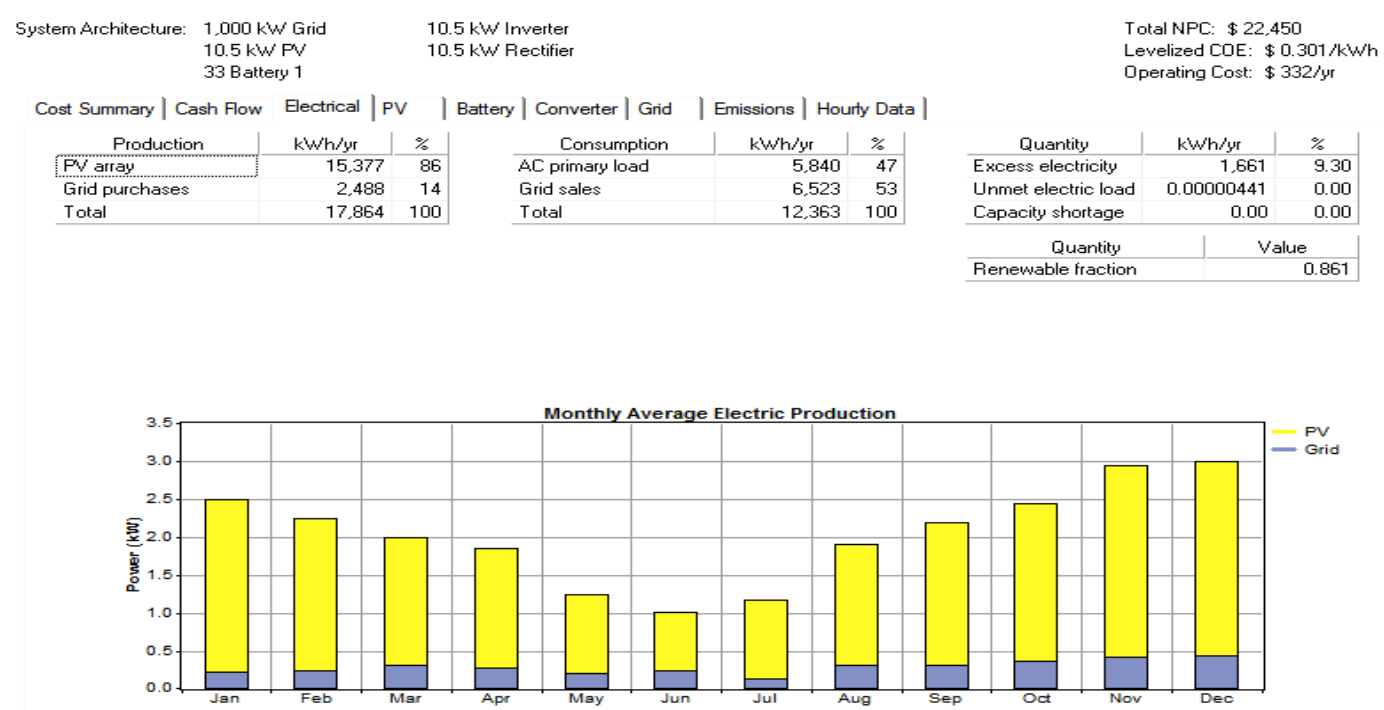

Fig. 9. Monthly average electricity production of system 2.

Sensitivity Results Optimization Results |

Double click on a system below for simulation results.

\begin{tabular}{|c|c|c|c|c|c|c|c|c|c|}
\hline 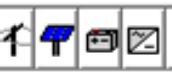 & $\begin{array}{l}\text { PV } \\
(\mathrm{kW})\end{array}$ & S4KS25P & $\begin{array}{l}\text { Conv. } \\
(\mathrm{kW})\end{array}$ & $\begin{array}{l}\text { Grid } \\
(\mathrm{kW})\end{array}$ & $\begin{array}{c}\text { Initial } \\
\text { Capital }\end{array}$ & $\begin{array}{l}\text { Operating } \\
\text { Cost }(\$ / y r) \\
\end{array}$ & $\begin{array}{l}\text { Total } \\
\text { NPC } \\
\end{array}$ & $\begin{array}{c}\mathrm{COE} \\
(\mathrm{S} / \mathrm{kWh})\end{array}$ & $\begin{array}{l}\text { Ren. } \\
\text { Frac. }\end{array}$ \\
\hline 1雨国 & 10.5 & 33 & 10.5 & 1000 & $\$ 18.210$ & 332 & $\$ 22,450$ & 0.301 & 0.86 \\
\hline
\end{tabular}

\section{E. $3^{\text {rd }}$ Approach (PV-Converter-Battery-Grid)}

The design of system 3 is as shown in the Fig. 11. The modeled system 3 is similar to system 2, but instead of 33 batteries 5 batteries were used. The system 3 was an attempt to decrease the COE by reducing the number of batteries to 5 instead of 33, and the attempt was successful.

89 percent of the PV output is used to supply house load, where as the remaining $8,807 \mathrm{kWh} / \mathrm{yr} \mathrm{AC}$ is sold to the grid, and the unmet electricity is purchased from the Grid. A negligible quantity of excess electricity i.e. AC $36.3 \mathrm{kWh} / \mathrm{yr}$ is stored in the battery as shown in Fig. 12. With the designed system an initial capital cost of $\$ 13,450$, operating cost of
\$ -193, \$10,979 NPC, levelized COE \$ 0.147/kWh 1, and RF 0.89 was obtained and shown in the Fig. 13.

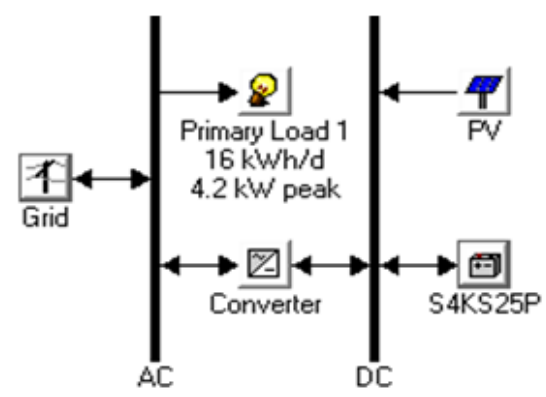

Fig. 11. System 3: PV- Converter- Grid. 

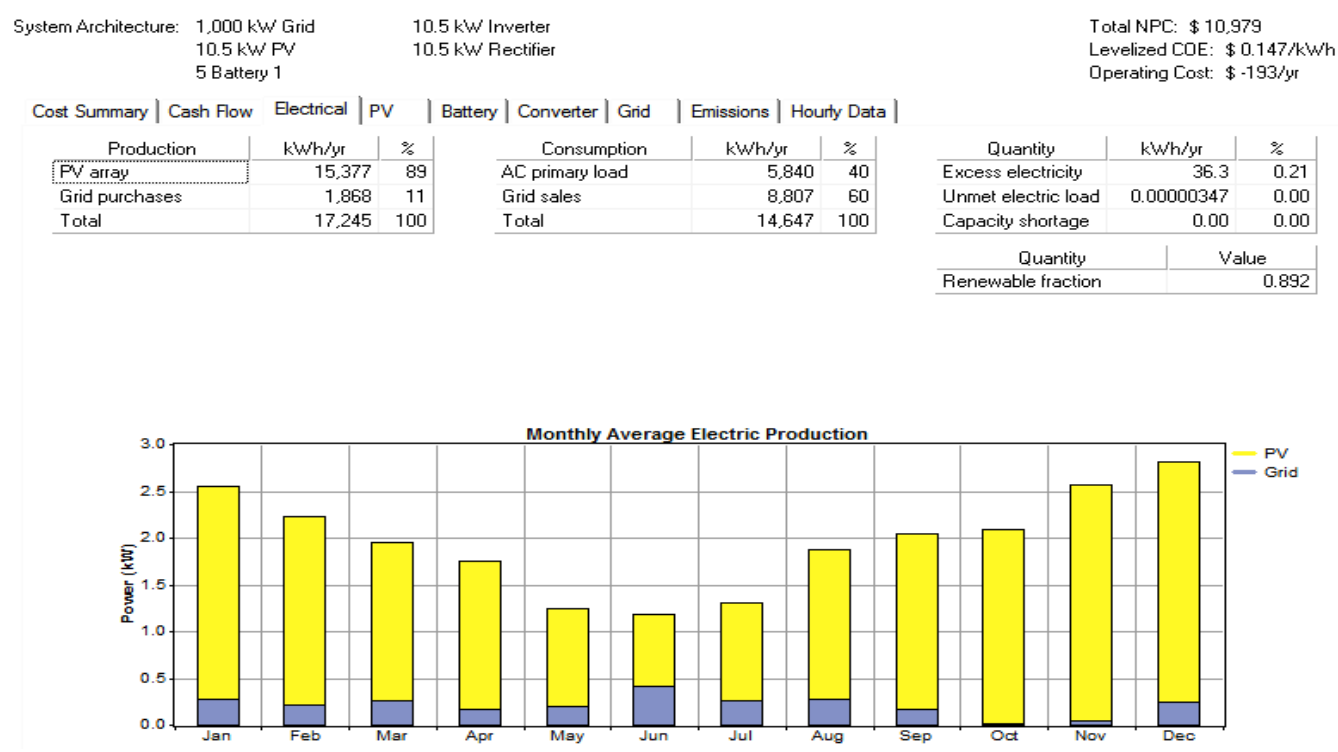

Fig. 12. Monthly average electricity production of system 3.

Sensitivity Results Optimization Results |

Double click on a system below for simulation results.

\begin{tabular}{|c|c|c|c|c|c|c|c|c|c|}
\hline $1 \%$ 田 & $\begin{array}{c}\text { PV } \\
(\mathrm{kW})\end{array}$ & S4KS25P & $\begin{array}{l}\text { Conv. } \\
(\mathrm{kW})\end{array}$ & $\begin{array}{l}\text { Grid } \\
(\mathrm{kW})\end{array}$ & $\begin{array}{c}\text { Initial } \\
\text { Capital }\end{array}$ & $\begin{array}{c}\text { Operating } \\
\text { Cost (\$/yr) }\end{array}$ & $\begin{array}{l}\text { Total } \\
\text { NPC }\end{array}$ & $\begin{array}{c}\mathrm{COE} \\
(\$ / \mathrm{kWh})\end{array}$ & $\begin{array}{l}\text { Ren. } \\
\text { Frac. }\end{array}$ \\
\hline 19甘 & 10.5 & 5 & 10.5 & 1000 & $\$ 13,450$ & -193 & $\$ 10.979$ & 0.147 & 0.89 \\
\hline
\end{tabular}

Fig. 13. System 3 optimized COE.

\section{F. $4^{\text {th }}$ Approach (PV-Converter- Grid)}

To overcome the escalating COE, battery was eliminated during the Power system design, and a fourth approach was designed as shown in the Fig. 14. System 4 is similar to system 2 and 3, whereas battery is eliminated.

Only 80 percent of the electricity produced from $\mathrm{PV}$ is used to supply electricity, where as the remaining electricity is purchased from Grid. The excess electricity of 11,770 $\mathrm{kWh} / \mathrm{yr}$ is sold to the grid as shown in the Fig. 15. From the designed system 4, an Initial capital cost of $\$ 12,600$, operating cost of $\$ 332, \$ 13,4760 \mathrm{NPC}$, levelized COE $\$ 0.184 / \mathrm{kWh}$, and RF 0.80 was obtained and shown in the Fig. 16.

A total of 14,096 kwh/yr of AC was produced from the RE systems after various system losses. Among the overall generated AC, only $5840 \mathrm{kwh} / \mathrm{yr}$ was used for the primary house load and the excess electricity was sold to the grid, and can be calculated using (13)

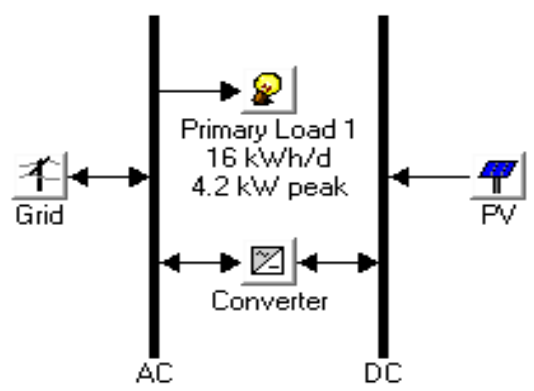

Fig. 14. System 3: Grid- PV- Converter.

\begin{tabular}{|c|c|c|c|c|c|c|c|c|c|}
\hline \multirow{2}{*}{$\begin{array}{l}\text { System Architecture: } \\
\text { Cost Summary | C }\end{array}$} & \multicolumn{2}{|c|}{$\begin{array}{l}1,000 \mathrm{~kW} \text { Grid } \\
10.5 \mathrm{~kW} / \mathrm{PV} \\
10.5 \mathrm{~kW} \text { Inverter }\end{array}$} & \multicolumn{2}{|r|}{$10.5 \mathrm{~kW}$ Rectifier } & & & \multicolumn{3}{|c|}{$\begin{array}{l}\text { Total NPC: } \$ 13,716 \\
\text { Levelized COE: } \$ 0.184 / \mathrm{kWh} \\
\text { Operating Cost: } \$ 87 / y \mathrm{r}\end{array}$} \\
\hline & ash Flow & Electrical | & $v$ & | Converter | Grid & Hourly Data & & & & \\
\hline \multicolumn{2}{|c|}{ Production } & $\mathrm{kW} / \mathrm{h} / \mathrm{yr}$ & $\%$ & Consumption & kWh/yr & $\%$ & Quantity & $\mathrm{kW} / \mathrm{h} / \mathrm{yr}$ & $\%$ \\
\hline \multicolumn{2}{|l|}{ PVarray } & 15,377 & 80 & AC primary load & 5,840 & 33 & Excess electricity & 0.000633 & 0.00 \\
\hline Grid purchases & & 3.771 & 20 & Grid sales & 11,770 & 67 & Unmet electric load & 0.00 & 0.00 \\
\hline Total & & 19,148 & 100 & Total & 17,610 & 100 & Capacity shortage & 0.00 & 0.00 \\
\hline & & & & & & & Quantity & & 0.803 \\
\hline
\end{tabular}

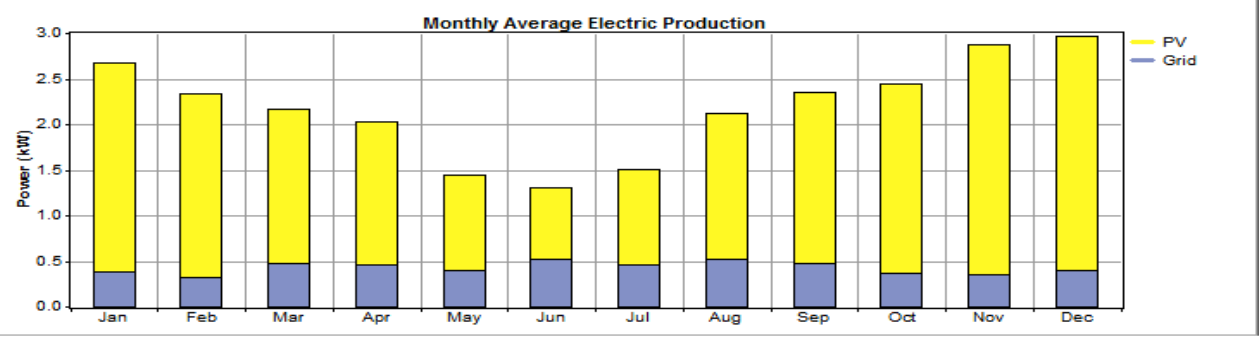

Fig. 15. Monthly average electricity production of system 4 . 
Sensitivity Results Optimization Results |

Double click on a system below for simulation results

\begin{tabular}{|c|c|c|c|c|c|c|c|c|}
\hline $14 \square$ & $\begin{array}{c}\mathrm{PV} \\
(\mathrm{kW})\end{array}$ & $\begin{array}{l}\text { Conv. } \\
(\mathrm{kW})\end{array}$ & $\begin{array}{l}\text { Grid } \\
(\mathrm{kW})\end{array}$ & $\begin{array}{c}\text { Initial } \\
\text { Capital }\end{array}$ & $\begin{array}{l}\text { Operating } \\
\text { Cost }(\mathbf{S} / \mathrm{yr})\end{array}$ & $\begin{array}{l}\text { Total } \\
\text { NPC }\end{array}$ & $\begin{array}{c}\mathrm{COE} \\
(\mathrm{s} / \mathrm{kWh})\end{array}$ & $\begin{array}{l}\text { Ren. } \\
\text { Frac. }\end{array}$ \\
\hline & 10.5 & 10.5 & 1000 & \$ 12.6 & 87 & s 13. & 0.184 & 0.80 \\
\hline
\end{tabular}

Fig. 16. System 4 optimized COE.

\section{G. $5^{\text {th }}$ Approach (Grid)}

The design of system 5 is as shown in the Fig. 17. The system 5 was modeled with an attempt to identify the current COE applicable to the house load at Geelong-Victoria state.

The entire house load was connected to the Grid system. The total AC house load i.e. 5,840 kWh/yr was supplied with the grid as shown in the Fig. 18. From the designed system 5 an initial capital cost of $\$ 0$, operating cost of $\$ 1,535, \$ 19$, $624 \mathrm{NPC}$, levelized COE $\$ 0.263 / \mathrm{kWh}$, and RF Zero was obtained as shown in the Fig. 19.

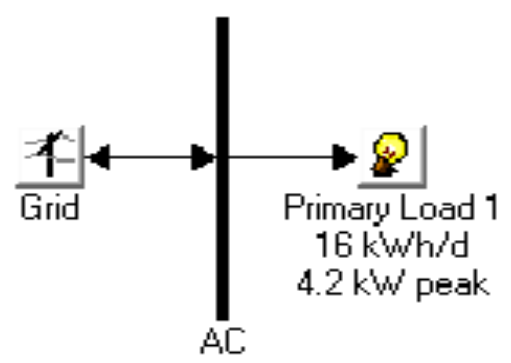

Fig. 17. System 5: Grid connected.
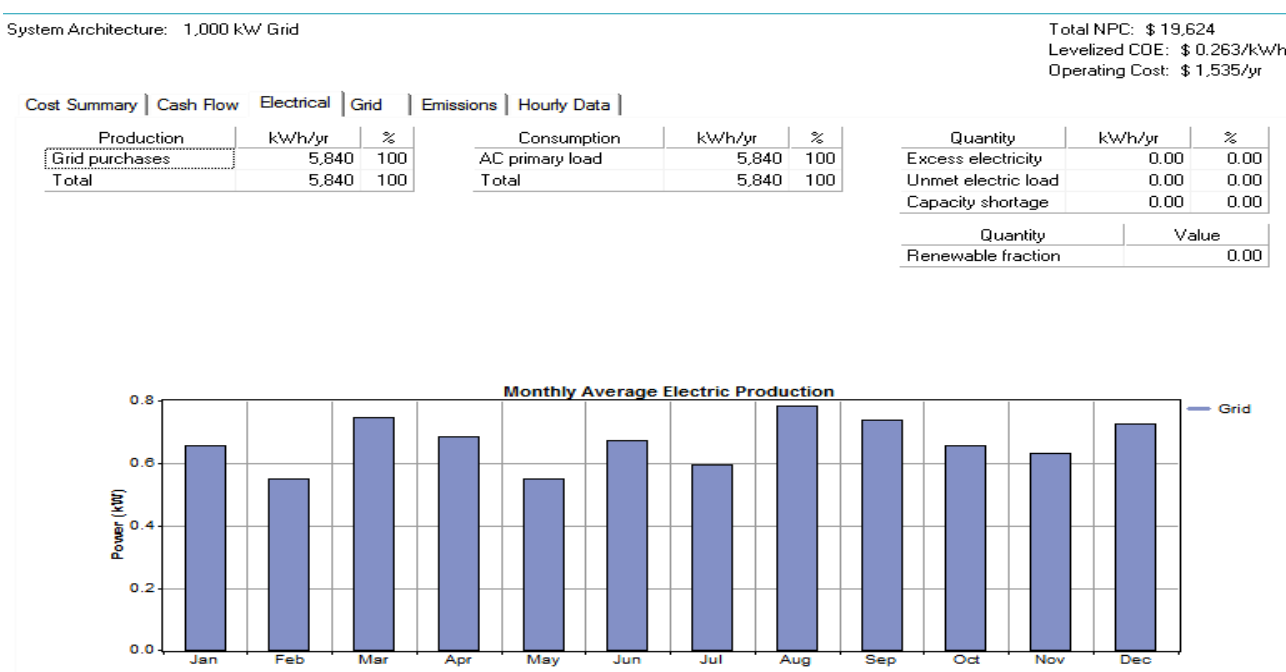

Fig. 18. Monthly average electricity production of system 5 .

Sensitivity Results Optimization Results |

Double click on a system below for simulation results.

\begin{tabular}{|c|c|c|c|c|c|c|}
\hline 1 & $\begin{array}{l}\text { Grid } \\
(\mathrm{kW})\end{array}$ & $\begin{array}{c}\text { Initial } \\
\text { Capital }\end{array}$ & $\begin{array}{l}\text { Operating } \\
\text { Cost }(\mathrm{S} / \mathrm{yr})\end{array}$ & $\begin{array}{l}\text { Total } \\
\text { NPC }\end{array}$ & $\begin{array}{c}\mathrm{COE} \\
(\mathrm{s} / \mathrm{kWh})\end{array}$ & $\begin{array}{l}\text { Ren. } \\
\text { Frac. }\end{array}$ \\
\hline & 1000 & & 1.535 & s 19. & 0.263 & 0.00 \\
\hline
\end{tabular}

Fig. 19. System 5 optimized COE.

\section{H. Emission}

The Emission released from system 1, 2, 3, 4, and 5 is as shown in the Fig. 20. System 1 emits zero emission, and system 5 emits significant emission, whereas system 2,3 , and 5 emits minimum quantity of emission when compared to system 5 . Therefore system 1, 2, 3, and 4 are considered to be environmental friendly power systems for future sustainability, as more than 80 percent of the electricity supplied to the house load is through RE source.

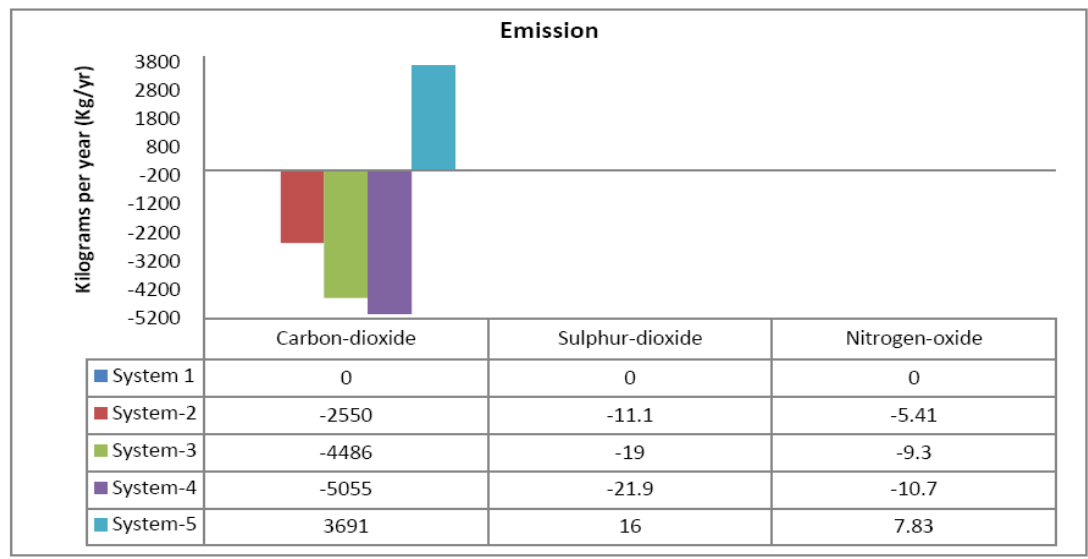

Fig. 20. Comparison of emission. 


\section{FUTURE WORK}

The pre-analysis study with HOMER for single residential load at Geelong has given an understanding and comparison of the proposed five systems. With the analytical analysis, it was revealed that system 3 is economical, emits less emission with 80 percent RF. However to validate the analytical results an experimental set up has to be implemented to investigate further.

\section{CONCLUSION}

Using HOMER software computer model, the comparison study was conducted. The analytical analysis of 5 systems gave an understanding of change in COE, Emission, RF parameter. Among the 5 systems I determined that system 3 has optimum COE, and emits considerably less emission in the atmosphere. In conclusion with the future target of 20-2020, electricity price increase, depletion of non renewable energy sources, environmental concerns and for future sustainability, it is now time to take an initiation to overcome these issues with a promising solution of using PV $\mathrm{RE}$ source with optimum batteries connected to grid in all residential and commercial buildings.

\section{REFERENCES}

[1] Bree-Energy Australia. Energy in Australia, Bree Energy, 2013.

[2] Victoria Solar Energy Council, Remote Area Power Supplies. Melbourne, Victoria, Australia: The State Electricity Commission of Victoria and Victoria Solar Energy Council, 1989.

[3] Australia Government, Department of resourses, Energy and Tourism. (2013) ret.gov.au. [Online]. Available: http://www.ret.gov.au/Department/Documents/clean-energy-future/E LECTRICITY-PRICES-FACTSHEET.pdf
[4] S. N. Geoff Stapleton, Grid Connected Solar Electric System, Frank Jackson, Ed. Newyork, Oxon: Earth scan, 2012.

[5] M. T. O. Amanullah, A. B. M. S. Ali, and M. T. Arif, "Investigation of energy storage systems, its advantage and requirement in various locations in Australia," Journal of Renewable Energy, pp. 1-15, 2013.

[6] A. R. M. T. Kahn, "Analysis of distributed energy resources for domestic electricity users," Journal of Energy in Southern Africa, vol. 23, no. 2, pp. 50-55, May 2012.

[7] M. Boxwell, Solar Electricity Handbook, 6th ed. UK: Greenstream Publishers, 2012.

[8] Garnaut, Australia's Emissions and the Economy, Garnaut Climate Change Draft Repoty.

[9] K. Bhattacharya and O. Hafez, "Optimal planning and design of a renewable energy based supply system for microgrids," Renewable Energy, vol. 45, pp. 7-15, 2012.

[10] Australian Government. (2012, August) Bureau of Metrology. [Online]. Available:

http://www.bom.gov.au/climate/data/index.shtml?bookmark=136\&zo om=3\&lat $=-37.1235 \&$ lon $=145$.2 \&layers $=$ B00000TFFFFFFFTFFFFF FFFFFFFFFFFFFFFTTT $\& d p=$ IDC10002-d

[11] B. K. Bhattarai, B. Sapkota, B. K. Khem, and N. Poudyal, "Estimation of global solar radiation using clearness index and cloud transmittance factor at trans-himalayan region in nepal," Scientific Research, pp. 1-7, November 2012

[12] G. N. Tiwari and S. Dubey, "Solar radiation," in Photovoltaic Modules and their Applications: Royal society of Chemistry, 2010, ch. 1, pp. $1-27$.

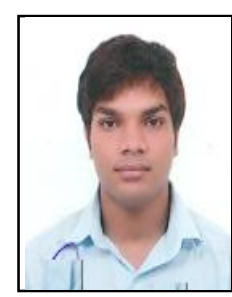

Harish Kumar R. N. is a member of IACSIT. He was born in Andhra Pradesh, India on 07/06/1989. $\mathrm{He}$ received Bachelors of Engineering (BE) Degree in Mechanical Engineering from Nitte Meenakshi Institute of Technology Bangalore, Karnataka stateIndia in the year 2011, and currently pursuing Masters of Engineering (Professional), with a specialization in Renewable Energy at Deakin university, Geelong, Victoria State-Australia. 